\title{
Strategies for Curbing Child Maltreatment: Implications for Child Development
}

\author{
Obumneke-Okeke, I.M.(Ph.D) ${ }^{1}$, Anyachebelu, F.E.(Ph.D $)^{2}$, Anyamene, \\ A.N.(Ph.D) $)^{3}$, Adebola, H.E.(Ph.D) ${ }^{4}$ \\ ${ }^{I}$ Department of Earlychildhood and Primary Education Nnamdi Azikiwe University, Awka Anambra State, \\ Nigeria \\ ${ }^{2}$ Department of Earlychildhood and Primary Education Nnamdi Azikiwe University, Awka Anambra State, \\ Nigeria \\ ${ }^{3}$ Department of Guidance and Counselling Nnamdi Azikiwe University, Awka Anambra State, Nigeria \\ ${ }^{4}$ Department of Adult Education Nnamdi Azikiwe University, Awka Anambra State, Nigeria
}

\begin{abstract}
For ages children have been victims of maltreatment, but for the past two decades the rate has taken a frightening dimension. Child maltreatment is the neglect of a child's survival and development needs, physical and emotional injury or harassment and the subjection of a child to measures, situations and experiences which interfere with a child's healthy development into adulthood. The study investigated causes, forms and strategies for curbing child maltreatment in Awka South Local Government Education Authority. 1023 primary school teachers constituted the population. Simple random sampling technique was used to select 360 teachers. Three research questions were raised to guide the study. A 20-item researchers developed questionnaire named Child Maltreatment Questionnaire (CMO) duly validated and reliability coefficient of 0.81 which was adjudged adequate for the research. A 4-point rating scale was used for data collection. Mean and frequency tables were used for data analysis. The findings revealed that causes of child maltreatment are personality problems of parents and lack of understanding in child development. Forms of child maltreatment are physical, sexual and emotional abuses, child labour and neglect. Strategies for curbing child maltreatment are supportive for parents against child abuse among others. Based on the findings, the researchers recommended that government should ensure that the fundamental human rights of the child is enforced from the home and that parents should be given proper information education on all forms of activity that constitutes child maltreatment for the proper development of the child.
\end{abstract}

Keywords: child maltreatment, curbing, development, implications, Strategies,

\section{Introduction}

Children are still grossly maltreated in Nigeria (Ebigbo, 2003). Although the nation is endowed with a rich natural and extensive human resources, yet it has not developed the necessary skills and ideas to pull its resources together in a sound economy and to take up care of the basic needs of its population (Ebigbo, 2003). As a result, poverty and hard living conditions are prevalent, affecting children in particular. He further explained that consumerism; an attitude of get rich quick and westernization have led to rural-urban migration and the emergence of urban poor. Hence children are caught up in the struggle for survival and material gain. Latimar (2003) defines child maltreatment as the mistreatment of a child or a disregard for the developmental needs of a child by a parent or caregiver, resulting in injury, emotional or psychological harm or the potential for such harm. He asserts that mounting evidence suggests that in addition to the immediate negative effects of maltreatment on children, there is associated with a host of problems that is manifested in adolescence and adulthood. These problems include fear, anxiety, depression, anger, hostility, inappropriate sexual behaviours, poor self esteem, tendency towards substance abuse and difficulty with close relationship.

According to Nweke (2002), maltreatment affects all spheres of a child's life which include the academic performance of a child thereby making him/her to be cognitively incapable as this portends more danger for manpower development and human resources of any nation. Child maltreatment is a common term that many experts use to describe child abuse and neglect. This term describes both abuse which include physical, sexual, emotional or psychological abuse and neglect which involves the failure to provide for a child's basic needs.

Goldman, Salus, Wolcott and Kennedy (2003) see child maltreatment as any act or failure to act on the part of a parent or caregiver that either results in death, serious physical or emotional harm, sexual abuse or exploitation or an imminent risk of serious harm on a child. They also assert that a child under this definition generally means a person who is under the age of 18 or who is not an emancipated minor.

The Federal Government of United States of America established a broad definition of child maltreatment in the Child Abuse Prevention and Treatment Act (CAPTA) by defining it as thus: 
The physical and mental injury, sexual abuse negligent treatment or maltreatment of a child under age 18 by a person who is responsible for child's welfare, under circumstances which indicate that the child's health and welfare is harmed and threatened (p.51).

Goldman et al (2003) claim that the above definition of child maltreatment specifies that only parents or caregivers can be perpetrators of a child abuse and neglect. Abusive behaviours by other individuals, whether they are known to the child or strangers is considered child assault.

Maltreatment of children can assume several forms. However there are four commonly recognized forms of child maltreatment. They are:

- Physical Abuse

- Neglect

- Sexual Abuse

- Emotional Abuse (Latimar, 2003, Goldman et al, 2003 \& Parke and Locke, 1998).

Physical abuse can be seen as the intentional non-accidental use of physical force or non-accidental acts of omission on the part of parents or other caretakers interacting with a child, aimed at hurting, injuring or destroying the child. It also takes the form of beating or battering the child which is characterized by physical injury such as bruises and fractures that results from punching, beating, kicking, biting, shaking, throwing, stabbing, choking, hitting and burning.

Neglect is the most common form of child maltreatment. Goldman et al (2003) posit that neglect is defined in terms of failure to provide for the child's basic needs which include deprivation of adequate food, clothing and shelter, supervision or medical care. It is generally characterized by omission in care resulting in significant harm or risk of significant harm.

Sexual abuse include a wide range of behaviours such as oral or genital penile penetration, genital contact with no intrusion, fondling of a child's breast, buttocks, indecent exposure, inadequate or inappropriate supervision of a child's voluntary sexual activities, use of a child in prostitution, pornography, internet crimes or other sexual exploitative activities.

Emotional or psychological abuse is described by Hodges (2001) as the habitual verbal harassment of a child by disparagement, criticism, threat and ridicule. He further explains that emotional abuse includes behaviours that threaten or intimidate a child for example name calling, belittling and shaming, hostility, rejection and reducing a child to ridicule and terrorizing.

According to Goldman (2003) these are strategies that may protect the child from vulnerability. These strategies fail under the following types-preventive strategies, protective, supportive and others which exist at individual, relational and community level. Preventive strategies should focus on these protective factors such as supportive family environment, nurturing of parental skills, stable family relationships, parental employment, access to healthcare and social services, community support for parents against child abuse and caring adults outside family who can serve as role models or mentors in order to eliminate the incidence of child maltreatment. Various forms of child maltreatment have been observed in Nigeria that affect the child's academic performance and which presumably makes them to be academically backward when compared with their counterparts from other developed countries like Britain, America and others. This study therefore sets out to investigate the causes, forms and strategies for curbing child maltreatment as perceived by primary school teachers.

\section{Research Questions}

The following research questions guided the study:

1. What are the causes of child maltreatment as perceived by primary school teachers?

2. What are the forms of child maltreatment as perceived by primary school teachers?

3. What are the strategies for curbing child maltreatment?

\section{Method}

Descriptive survey design was used for the study. The area of study was Awka South Local Government Education Authority. Three research questions guided the study, 1023 primary school teachers constituted the population of the study. Simple random sampling technique was used to select 360 teachers from 30 schools. The instrument for the study was a 20 -item researchers developed questionnaire titled Child Maltreatment Questionnaire (CMQ) structured on four point rating scales of Strongly Agree (4 points), Agree(3 points), disagree (2 points), and Strongly Disagree(1point) which was used for data collection. The structured instrument is made up of four parts A, B, C, D. Apart A sought such demographic information as name of school, local government area and location of school, part B sought information on causes of child maltreatment, Part C sought for forms of child maltreatment while part D sought for the strategies for curbing child maltreatment. The instrument were validated by experts in Early child education and Guidance and counseling. The reliability coefficient value of the instrument was 0.84 . Data collection was done by the researchers and two 
trained assistants. Mean scores of 2.50 and above were accepted as being positive while mean score below 2.50 were rejected as negative.

\section{Results}

The results are presented in order of the research questions.

Research Question 1

TABLE 1: Mean Responses on causes of Child Maltreatment

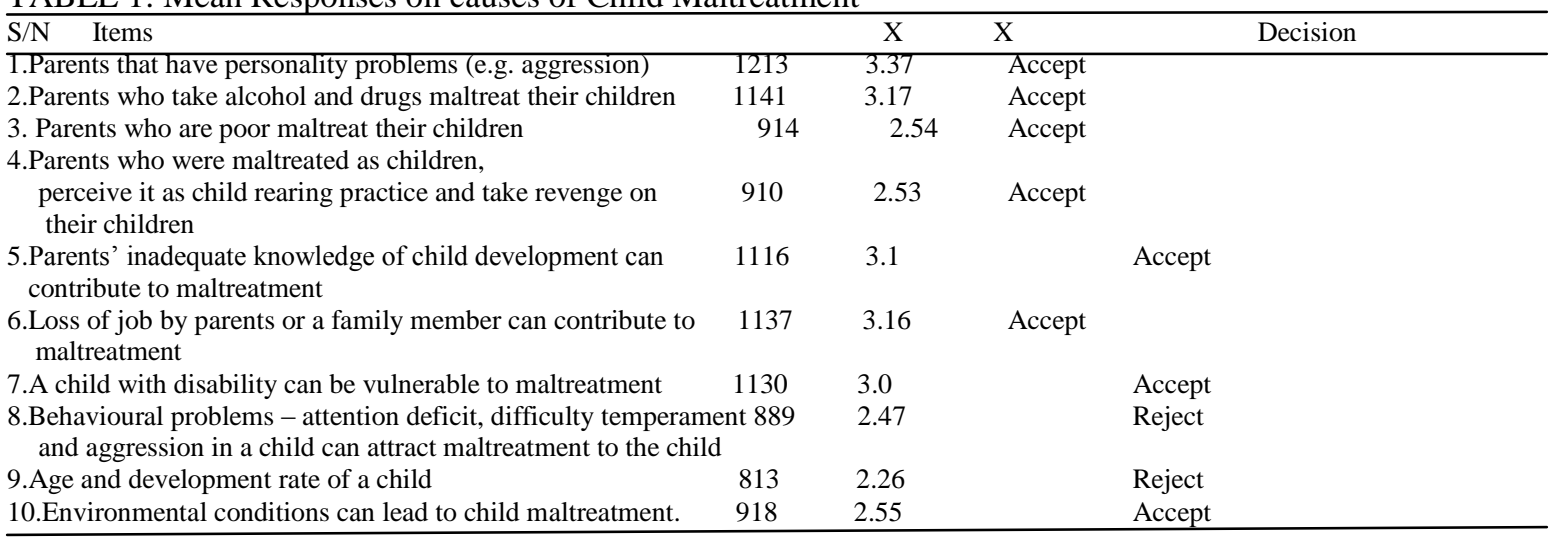

Table 1 reveals that out of the ten items on the perceived causes of child maltreatment eight was accepted. All the items scored above 2.50 except items 8 and 9 which were not seen as causes of child maltreatment. It then showed that these items except 8 and 9 are perceived as the causes of child maltreatment.

Research Question 2

TABLE 2: Mean Responses on forms of Child Maltreatment

\begin{tabular}{|c|c|c|c|c|}
\hline $\mathrm{S} / \mathrm{N} \quad$ Items & & $\mathrm{X}$ & $\mathrm{X}$ & Decision \\
\hline 3. Manual labour in hazardous conditions & 1321 & 3.67 & Accept & \\
\hline 5.Making a child to feel flawed, worthless, unloved, & 1227 & 3.41 & & Accept \\
\hline
\end{tabular}

$\begin{array}{llll}\text { 5.Making a child to feel flawed, worthless, unloved, } & 1227 & 3.41 & \text { Accept }\end{array}$

In table 2, all the items scored above 2.50 which means that the teachers perceived all the items as forms of child maltreatment. This is worrisome because children's academic performance depends much on their emotional stability which if not stable will invariably affect their learning.

Research Question 3

TABLE 3: Mean Responses on Strategies for Curbing Maltreatment

\begin{tabular}{|c|c|c|c|c|}
\hline S/N Items & & $\mathrm{X}$ & $\mathrm{X}$ & Decision \\
\hline 1.Supportive family environment & 1263 & 3.51 & Accept & \\
\hline 2.Stable family relationships & 1094 & 3.04 & Accept & \multirow{3}{*}{ Accept } \\
\hline 3. Adequate housing and access to health care and social se & es1033 & \multicolumn{2}{|c|}{2.87} & \\
\hline 4.Parental employment/household child monitoring & 957 & 2.66 & Accept & \\
\hline $\begin{array}{l}\text { 5.Communities that support parents and take responsibility } \\
\text { of preventing abuse }\end{array}$ & 1206 & 3.35 & & Accept \\
\hline
\end{tabular}

Table 3 reveals that all the items scored above 2.50 which means that all the strategies as perceived by the teachers will be used in curbing child maltreatment and if done will provide a balanced and democratic classroom atmosphere which will invariably make for better academic performance.

\section{Discussion}

The findings from research question one showed that the teachers perceived causes of child maltreatment are parental personality problems, poverty, alcohol intake by parents, behavioral problems of the child, among others. The findings corroborate with Nweke's findings (2002) whose results showed that the problems of child maltreatment affect all spheres of his/her which include the academic performance. This finding also agrees with Latimar (2003) and Goldman et al (2003). They state that parents' personality characteristics, substance abuse, attitude and knowledge of parents, problems in family, poverty and child personality and community characteristics are interactive, leading to child maltreatment. The findings of research question two indicate an agreement with what the teachers perceived as forms of child maltreatment to include physical, emotional and sexual abuse, child neglect and child labour. These findings are in agreement with the views of Ebigbo (2003) which states that child maltreatment can take the form of physical sexual and emotional abuses, neglect and child labour. The consequences of child maltreatment include poor academic 
performance, physical disabilities, drug and alcohol addiction, involvement in criminal and violent activities, frustration and unhappiness in later life. The child should not be maltreated for the above mentioned reasons so that he/she will develop a balanced personality. UNICEF (2000) states that child maltreatment can be injurious to the physical, social, cognitive and moral development of a child. The findings are supportive family environment, stable family relationships, adequate housing and access to health care and social services, parental employment, household rules, child monitoring, community support and prevention of abuse. These findings have implications for child development. This implies that these should be a proper understanding of the child's developmental needs, a more understanding attitude from the parents as well as influences from the family and the environment (the community). The significant group in child training and upbringing should consider the cost of child maltreatment vis-à-vis its long run implications on the personality of the child. Studies (Ebigbo, 2003, Uzodike 2004) have shown that children who are maltreated during childhood end up constituting a larger population of societal misfits and socially maladjusted individuals, therefore parents, teachers and others should take appropriate measures to curb the incidence of child maltreatment. Lala (1989) suggest the inclusion of parent education programmes for parents with young children and families who have children with special needs (disabilities) plus families living in low income neighbourhoods. He also noted that the child's relationship with other family members in the home will enhance his learning abilities in the school.

\section{Conclusion}

Based on the findings of the study, conclusions were drawn. Child maltreatment are caused by some interactive factors which include parental, child, environmental and family factors, the forms include physical abuse, neglect, child labour and emotional abuses. Strategies for curbing child maltreatment are supportive family environment and stable family. This implies that a proper solution of child maltreatment can only be solved by a proper understanding of the child's developmental needs and a more understanding attitude from the parents, family and environment since the study revealed the major causes and forms of child maltreatment/strategies for curbing the act. The teacher should be able to detect the various forms of child maltreatment that might affect the proper growth and development of the child. Teachers should be able to educate parents on the strategies to take in order to curb child maltreatment.

\section{Recommendations}

Based on the findings of the study, the following recommendations were made:

1. The government should give appropriate legislation and enforcement of the fundamental rights of the child whereby the rights of the child is protected and respected by parents.

2. Parents should be given proper education on all forms of activity that constitute child maltreatment. This can be done through seminars and sensitization programmes.

3. Teachers of the young children should be well informed to desist from any act that will lead to the violation of fundamental rights of the child.

4. Parents to partner with teachers in identifying maltreated children whose academic performance is affected by giving them a sense of belonging to ensure overall development of the child.

\section{Books:}

\section{References}

[1]. P.O. Ebigbo, Street children: The care of child abuse and neglect in Nigeria. (Enugu: Obuka Press,2003).

[2]. J. Latimar, The consequences of child maltreatment: A reference guide for health practitioners. (Canada: Slough Buck Hollen Street Press Ltd, 2003).

[3]. C. Nweke, Abuse prevention education, A publication by women action coalition child abuse and forum for African women educationist Nigeria.( Anambra :Art love and Graphic production. Nimo, 2002).

[4]. A. Goldman, T. Salus, C. Wolcott, \& W. Kennedy, Child maltreatment and prevention. (USA: McGraw-Hill Company, 2003)

[5]. R.D. Parke \& V.O. Locke, Child psychology : A contemporary view point. (New Jersey: McGraw-Hill company, 1998)

[6]. T. Hodges, Children's and women's rights in Nigeria: A wake-up call situation assessment and analysis. (Lagos: UNICEF Publications, 2001)

[7]. Unicef, Nigeria and the convention on the rights of children: A workbook for Nigerian junior secondary school students.(Lagos: UNICEF Publications 2000)

[8]. E. Uzodike, Child abuse and neglect in Nigeria: Socio-legal aspects. (Lagos:University press, 2006)

[9]. B.C. Lala, Child welfare policies and practice. (USA: McGraw-Hill Company, 1989)

[10]. J.A. Foley, Child abuse and neglect in Nigeria. ( Fitchburg: State college press, 2005)

[11]. B. Oloko, Children's work in urban Nigeria: A case of young children. (Dublin: Gill Macmillan publishers, 1994)

[12]. D.H. Sailor, Supporting children in their home, school and community. (USA: Pearson Education Inc, 2004)

[13]. A. Woolfook, Education psychology. (Boston: Allyn and Bacon, 2004)

Journal Papers:

[14]. P.O. Ebigbo, Situation analysis of child abuse and neglect in Nigeria making use of Nigerian daily newspapers, Journal of African Psychology (1), 1989, 95-101. 